\title{
VALORIZATION OF SIDA CORDIFOLIA L. BIOMASS IN COMPOST FOR PEARL MILLET (PENNISETUM GLAUCUM) PRODUCTION IN NIGER
}

\author{
Maman Sadi Souley 1, 2, Saidou Addam Kiari ${ }^{2}{ }^{\square}$ iD , Boubé Morou ${ }^{1}$, Jens B. Aune ${ }^{3}$ \\ 1 Université Dan Dicko Dankoulodo de Maradi, BP 465, Maradi, Niger Tel 20410132 \\ 2 Département De Gestion Des Ressources Naturelles/ INRAN Niamey, Niger \\ ${ }^{3}$ Department of International Environment and Development Studies, Norwegian University of \\ Life Sciences, 1430 Ås, Norway
}

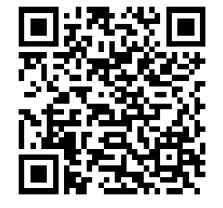

DOI: https://doi.org/10.29121/granthaalayah.v8.i11.2020.2317

Article Type: Research Article

Article Citation: Maman Sadi

Souley, Saidou Addam Kiari, Boubé

Morou, and Jens B. Aune. (2020).

VALORIZATION OF SIDA

CORDIFOLIA L. BIOMASS IN

COMPOST FOR PEARL MILLET

(PENNISETUM GLAUCUM)

PRODUCTION IN NIGER.

International Journal of Research -

GRANTHAALAYAH, 8(11), 211-226.

https://doi.org/10.29121/granthaa

layah.v8.i11.2020.2317

Received Date: 02 November 2020

Accepted Date: 30 November 2020

Keywords:

Sida Cordifolia L.

Biomass

Composting

Chemical Composition

Pearl Millet Yield

\section{ABSTRACT}

Sida cordifolia L. (SC) is an invading species that represents a threat to grazing lands in Niger. In order to enhance this invasive species, we studied the use of this plant for compost-making. First, the study evaluated the development of chemical properties under aerobic composting of SC in pit $(\mathrm{P})$ and in heap $(\mathrm{H})$ composting with two different mixtures. Mixture 1 (M1) contained 75\% SC, 20\% manure and $5 \%$ ash, while mixture 2 (M2) contained 95\% SC and 5\% manure. Then, the phytotoxicity test of the composts obtained was carried out by evaluating the effects of four different concentrations of compost on germination of pearl millet. The study of the effect of the rates $1000 \mathrm{~kg} \mathrm{ha}^{-1}$ and $1500 \mathrm{~kg} \mathrm{ha}^{-1}(100 \mathrm{~g}$ and $150 \mathrm{~g}$ hill- $^{-1}$ ) of the different composts on pearl millet yield under field conditions. The composting was undertaken at Molli fishery station and the agronomic tests at the N'Dounga experimental site during two seasons (2018 and 2019). The chemical analysis showed that the composts from M1 were richer in plant nutrients than the M2 composts. All four rates of composts gave germination rates beyond $50 \%$ independent of composting method or compost mixture. On both seasons, the $1000 \mathrm{~kg} \mathrm{ha}^{-1} \mathrm{M} 1 \mathrm{P}$ gave the best result in terms of grain yield. In 2018, M1P treatment increased grain yield compared to the control by $652 \mathrm{~kg} \mathrm{ha}^{-1}(105.2 \%)$, while in 2019, the corresponding yield increase was $812 \mathrm{~kg} \mathrm{ha}^{-1}(118.02 \%)$. Application of $1000 \mathrm{~kg} \mathrm{M} 1$ compost ha-1 corresponded to about $11.1 \mathrm{~kg} \mathrm{~N} \mathrm{ha}^{-1}$, which is more than three times the amount of $\mathrm{N}$ applied when using the recommended rate of $20 \mathrm{~kg} \mathrm{NPK} \mathrm{ha}^{-1}$ as micro dosing. This result showed that compost of SC can be used as a supplement to mineral fertilizer for increasing pearl millet yield.

\section{INTRODUCTION}

Population growth in Niger is about 3\%, which means that food production must double in 50 years in order to keep pace with population growth. Farmers are poor and their use of mineral fertilizer is therefore low. There is consequently a need to develop alternative and less costly soil fertility management options. Compost and green manures can be alternatives or supplements to mineral fertilizer. Many studies from the region shows that compost can greatly increase yield. In Burkina Faso sorghum yield increased by $45 \%$ as a result of application of $5 \mathrm{Mg}$ compost ha $^{-1}$ and compost application was able to compensate for late sowing (Ouédraogo et al. 2001). In Niger it was found that a compost produced from millet glume and farm yard manure was able to increase pearl millet grain yield by

(C) 2020 The Author(s). This is an open access article distributed under the terms of the Creative Commons Attribution License, which permits unrestricted use, distribution, and reproduction in any medium, provided the original author and source are credited. 
59.4\% when 1.5 Mg compost ha-1 was applied as micro dosing (hill placement of manure) (Issoufa et al. 2019). This study also found that application of compost greatly improved the agronomic efficiency of mineral fertilizer and increased soil microbial biomass. A long-term trial in Niger with annual application of organic matter also showed that organic matter application is of vital importance for maintaining the long-term productivity of the soil (Bationo and Buerkert 2001). Application of organic amendments have been found to increase phosphorous availability, stimulate root growth and increase water holding capacity of soil (Bationo and Buerkert 2001). This study also showed that the importance of application of organic amendment was higher in the drier Sahelian zone than in the more humid Sudanian zone. Furthermore, organic amendments were particularly important for increasing pearl millet yields in years with low rainfall.

However, the availability of organic amendment is a problem in the Sahel. In Niger is was shown that only $21 \%$ of millet stover produced was available for mulching (Baidu-Forson 1995). Manure is also in low supply as a results of limited number of animals and the quality of the rangeland (Bationo and Buerkert 2001). An additional problem is also that the chemical properties of organic amendment including compost are of poor quality as the chemical properties reflect the soil fertility of the soils from which biomass for the compost was produced (Bationo and Buerkert 2001). There is therefore a need to find alternative biomass sources for producing compost and the use of Sida cordifolia L. (SC) can be an interesting approach because biomass from SC is easily available. SC is an herbaceous plant of the family of the Malvaceae. This species was not previously abundant in grazing areas in Niger, but its presence in pastures has increased rapidly in recent decades(Saadou 1990). The species is not grazed by animals and is typically found in animals' passage corridors in agro-pastoral zones (Chaibou 2000). Currently, SC occupies important areas of agro pastoral areas in Niger and is considered an invasive species. SC occupied between 96 and $100 \%$ of pasture are in the two villages (Tientergou and Bangou) in Niger (Chaibou 2000).This study therefore accessed the use of $\mathrm{SC}$ as material for compost production and its use has as a fertilizer in pearl millet production.

The objective of this study was to valorize the biomass of SC through composting, assess phytotoxicity on germination, and evaluate the effect of compost on grain yield and stover production of pearl millet.

\section{MATERIAL AND METHODS}

\subsection{STUDY ZONES}

The study of compost (elaboration and phytotoxicity test) was conducted in 2018 at Molli fishery station located about 35 kilometers at the south-East of Niamey on longitude $2^{\circ} 20^{\prime} 149^{\prime \prime}$ Est and latitude $13^{\circ} 18^{\prime} 511^{\prime \prime}$ North.

The agronomics experiments were conducted during the 2018 and 2019 at the Centre Régional de Recherche

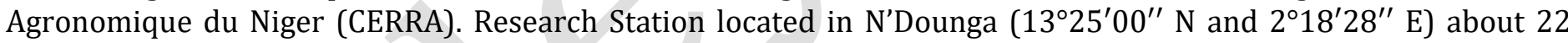
kilometers at the south-East of Niamey (figure 1).

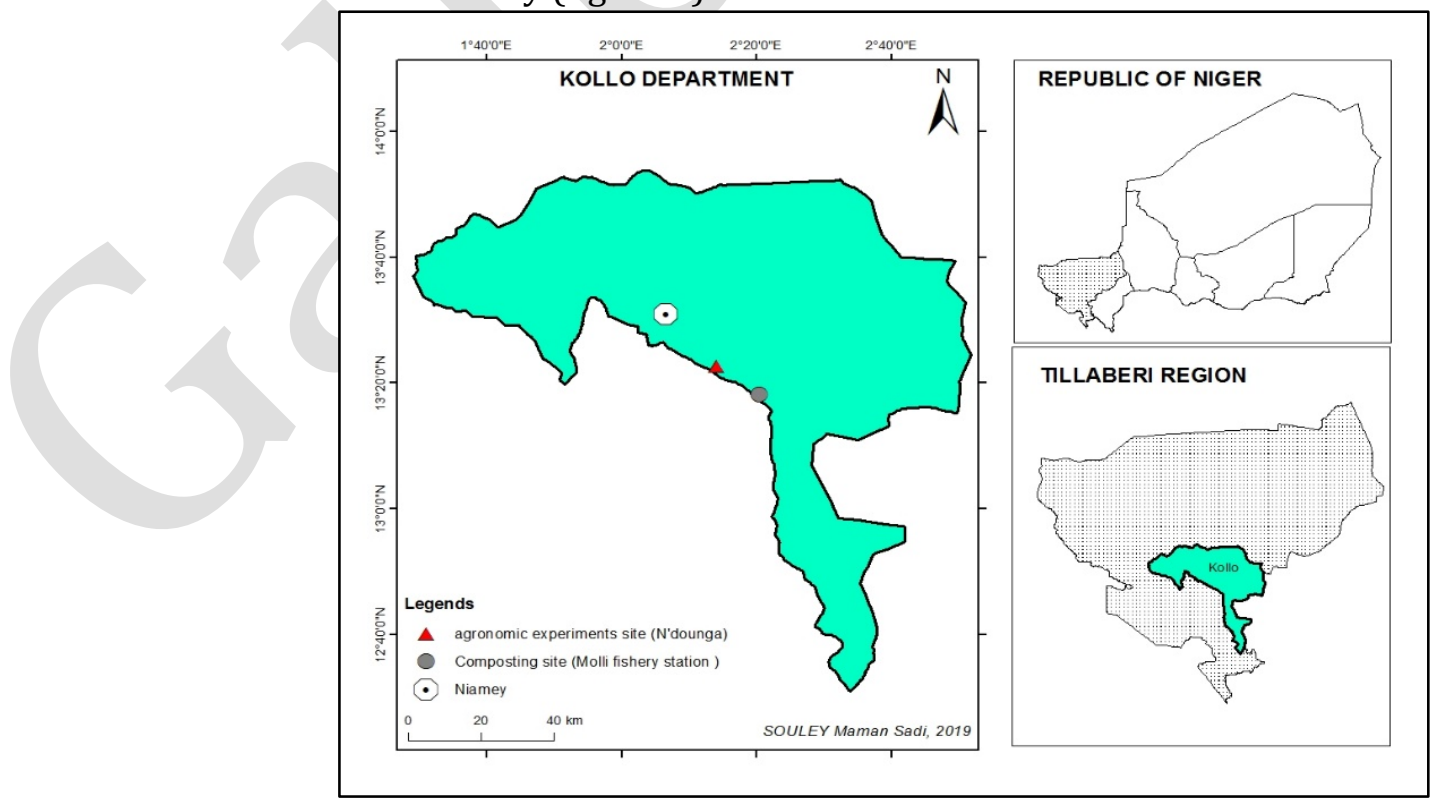

Figure 1: Location of experimental sites. 
The climate of the study zone is of Sahelo-Sahelian type with an average yearly rainfall of $482 \mathrm{~mm}$. The average temperatures are around $30^{\circ} \mathrm{C}$ in the dry season. The soils are classified as Psammentic Paleustalf (FAO, 1988) which is sandy, with moderate to low inherent soil fertility.

The soil in the site (Table 1) are preponderantly sandy, low in organic matter and deficient in both nitrogen and phosphorus (Sadi et al. 2019).

Table 1: Initial soil physical and chemical properties per site $( \pm \mathrm{SE})$

\begin{tabular}{|c|c|c|}
\hline Measured parameters & Unit & Mean of values per site (depth 0-20 cm) \\
\hline $\mathrm{pH}-\mathrm{H}_{2} \mathrm{O}(1: 2.5)$ & & $6.77 \pm 0.1$ \\
\hline Carbon & $\%$ & $0.16 \pm 0.01$ \\
\hline Total nitrogen & $\%$ & $0.02 \pm 0.002$ \\
\hline Available phosphorus & $\mathrm{mg} \mathrm{kg}^{-1}$ & $12.81 \pm 8.11$ \\
\hline \multicolumn{3}{|c|}{ Exchangeable bases $^{-3}$} \\
\hline $\mathrm{Ca}^{2+}$ & $\mathrm{mg} \mathrm{kg}^{-1}$ & $7.6 \pm 0.08$ \\
\hline $\mathrm{Mg}^{2+}$ & $\mathrm{mg} \mathrm{kg}^{-1}$ & $1.2 \pm 0.40$ \\
\hline $\mathrm{Na}^{+}$ & $\mathrm{mg} \mathrm{kg}^{-1}$ & $7.13 \pm 0.92$ \\
\hline $\mathrm{K}^{+}$ & $\mathrm{mg} \mathrm{kg}^{-1}$ & $39.9 \pm 18.4$ \\
\hline \multicolumn{3}{|c|}{ Granulometry } \\
\hline $\mathrm{Clay}$ & $\%$ & $0.72 \pm 0.04$ \\
\hline Silt & $\%$ & $4.78 \pm 0.41$ \\
\hline Sand & $\%$ & $94.5 \pm 1.3$ \\
\hline
\end{tabular}

\subsection{EXPERIMENTAL MATERIAL}

The material used for the composting was dry biomass of SC, organic manure (OM) and ash. The biomass of the SC (stems, leaves, flowers, seeds) was harvested at maturity between October and November 2017. The OM (a mixture of the straw and dejections of bovines) was collected in the village of Molli close to Kollo INRAN station where the test was conducted. The OM was cow dung and crop residues having served to feed the animals. Wood ash was also collected from the Molli village.

The soil used for the phytotoxicity test was collected at N'Dounga research station. where the agronomic experiments were carried out.

The variety of pearl millet Haini Kiré Précoce (HKP) was used in the germination test and in the field experiments. It has a growth cycle of 90 days and plant height varies from 1.9 to $2.0 \mathrm{~m}$. This variety can yield up to 2 t ha- ${ }^{-1}$ under good conditions.

\subsection{METHODS OF COMPOSTING}

The composting methods tested were pit (P) and heap (H) composting under aerobic conditions. The dimensions of the pit were $3 \times 3 \times 1 \mathrm{~m}$. In the heap method, the diameter of the heap at the ground was $1.5 \mathrm{~m}$ and the height $1 \mathrm{~m}$.

Two types of compost mixture were used in this study. Mixture 1 (M1) consisted of $75 \%$ of the $S$. cordifolia L. biomass (SCB) $+20 \%$ Organic Manure (OM) $+5 \%$ ash and mixture 2 (M2) consisted of 95\% of SCB + 5\% OM. The compost treatments were as follows:

1) M1P: $75 \% \mathrm{SCB}+20 \% \mathrm{OM}+5 \%$ ash in the pit,

2) M2P: $95 \% \mathrm{SCB}+5 \% \mathrm{OM}$ in the pit,

3) M1H: $75 \% \mathrm{SCB}+20 \% \mathrm{OM}+5 \%$ ash in heap,

4) $\mathrm{M} 2 \mathrm{H}: 95 \% \mathrm{SCB}+5 \%$ OM in heap.

SCB was first cut into pieces of about 10-15 cm long to accelerate decomposition. The materials were positioned in successive layers (Misra et al. 2005). About 85 liters of water was added before covering the mixture with tarpaulin. Generally, the optimal humidity of the mixture is situated between 50 and $80 \%$ of the raw mass (Richard 
et al. 2002). Every pit/heap was mixed twice per week during the first month (therefore two chambers in the pit). Thereafter, the pit/heap was turned once per week.

During the process of composting, the temperature of the mixtures was measured daily with the help of a probe thermometer. Every month, a composite sample was collected for analysis of $\mathrm{pH}$, carbon, nitrogen, phosphorus and potassium.

The pH was measured with the Mettler-Toledo type MP 225 (ISO 19390 (1994). The total organic carbon was determined according to the method Walkley and Black (Walkley and Black 1934). Total nitrogen was measured using Kjeldahl method (NT 76.05, 1983). Available phosphorus was determined by Bray I method (Van Reeuwijk 1993). Potassium $\left(\mathrm{K}^{+}\right)$was determined with the help of a flame photometer (Lange $\mathrm{M} 7$ ).

\subsection{TEST OF PHYTOTOXICITY ON PEARL MILLET}

A germination test was undertaken at CERRA Kollo Greenhouse at $25^{\circ} \mathrm{C}$ to assess the effect of the different types of compost (treatments) on pearl millet germination. A randomized pot experiment with four repetitions was used. The composts M1P, M1H, M2P and M2H were tested in combination with four concentrations of compost (S1=100\% compost, S2=75\% compost and $25 \%$ sand, $S 3=25 \%$ compost and $75 \%$ sand and $S 4=100 \%$ sand). The soil was collected at N'Dounga research station. The treatments were tested in pots with $17 \mathrm{~cm}$ of diameter and $10 \mathrm{~cm}$ depth. In every pot, 100 seeds of the pearl millet variety HKP were sown for the germination test. The germination was recorded by counting daily the number of germinated seeds during a 10 days period. Irrigation was provided according to needs of the plants.

\subsection{FIELD EXPERIMENT}

A field experiment was also undertaken to assess the effects on pearl millet yield of the different types of compost. The treatments were as follows:

1) Control;

2) $1000 \mathrm{~kg} \mathrm{ha}^{-1} \mathrm{M} 1 \mathrm{P}$;

3) $1500 \mathrm{~kg} \mathrm{ha}^{-1} \mathrm{M} 1 \mathrm{P}$;

4) $1000 \mathrm{~kg} \mathrm{ha}^{-1} \mathrm{M} 2 \mathrm{P}$;

5) $1500 \mathrm{~kg} \mathrm{ha}^{-1} \mathrm{M} 2 \mathrm{P}$;

6) $1000 \mathrm{~kg} \mathrm{ha}^{-1} \mathrm{M} 1 \mathrm{H}$;

7) $1500 \mathrm{~kg} \mathrm{ha}^{-1} \mathrm{M} 1 \mathrm{H}$;

8) $1000 \mathrm{~kg} \mathrm{ha}^{-1} \mathrm{M} 2 \mathrm{H}$;

9) $1500 \mathrm{~kg} \mathrm{ha}^{-1} \mathrm{M} 2 \mathrm{H}$.

The experiment was completely randomized with four replications. Each plot measured $5 \mathrm{~m} \times 6 \mathrm{~m}$ spaced with $2 \mathrm{~m}$ between each plot. An alley of $3 \mathrm{~m}$ separated the repetitions. The spacing was $1 \mathrm{~m}$ within and between rows

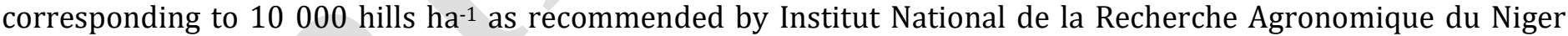
(INRAN). The compost was applied at sowing. The plants were thinned to two plants hill-1 during the first weeding. At physiological maturity, grain yield and biomass were harvested from the 4 central rows (16 hills) of each plot. The samples were air dried in the sun for two weeks.

In order to appreciate how much productivity improvement was gained by use of the nutrients inputs and how productive the cropping system is relative to its nutrient input, agronomic efficiency was calculated from the formula developed by (Vanlauwe et al. 2011) as follows:

AE- $\mathrm{N}\left(\mathrm{kg}\right.$ grain. $\left.\mathrm{kg}^{-1} \mathrm{~N}\right)=\frac{y-y_{0}}{F_{n}}$ where:

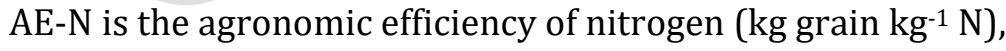

$\mathrm{Y}$ is the grain yield of the fertilized plot in $\mathrm{kg} \mathrm{ha}^{-1}$,

$\mathrm{Y}_{0}$ is the grain yield of the control plot in $\mathrm{kg} \mathrm{ha}^{-1}$ and

$\mathrm{F}_{\mathrm{n}}$ is the quantity of nitrogen contained in the applied compost. 


\subsection{ANALYSIS OF DATA}

The data for every variable were tested for their normal distribution with the Ryan Joiner test. An analysis of variance (ANOVA) was used to test for significant differences. The means were separated based on the Tukey's test. The software Excel 2016 and Minitabs 14th edition was used for these analyses.

\section{RESULTS}

\subsection{VARIATION OF THE PHYSICO CHEMICAL PROPERTIES DURING COMPOSTING}

A significant variability in carbon, nitrogen and organic matter content was observed during composting process (Table 2). Analysis of the variance showed highly significant differences in physico-chemical elements (C, N, $\mathrm{OM}$ ) between the composts and between the times (<.001). For $\mathrm{pH}$, no significant difference appeared.

Table 2: ANOVA of physicochemical elements according to composts and time

\begin{tabular}{|c|c|c|c|c|c|}
\hline \multirow[t]{2}{*}{ Compost } & \multirow[t]{2}{*}{ Times } & \multicolumn{4}{|c|}{ Physicochemical elements } \\
\hline & & Carbon (\%) & Organic matter (\%) & Nitrogen (\%) & $\mathrm{pH}-\mathrm{H}_{2} \mathrm{O}$ \\
\hline \multirow[t]{3}{*}{ M1P } & T1 & $13.02^{i}$ & $22.43^{h}$ & $0.83^{c}$ & 8.31 a \\
\hline & $\mathrm{T} 2$ & $12.90^{\mathrm{h}}$ & $22.23 \mathrm{~g}$ & $0.80^{b}$ & $8.01^{\mathrm{a}}$ \\
\hline & T3 & $12.31^{\mathrm{g}}$ & $21.21^{\mathrm{f}}$ & $1.11 \mathrm{e}$ & $8.07 \mathrm{a}$ \\
\hline \multirow[t]{3}{*}{ M2P } & T1 & $12.97^{i}$ & $22.35 \mathrm{~g}$ & $0.77 \mathrm{~b}$ & 8.18 a \\
\hline & $\mathrm{T} 2$ & $11.70^{\mathrm{f}}$ & $20.16^{\mathrm{d}}$ & $0.78 \mathrm{~b}$ & $7.76^{\mathrm{a}}$ \\
\hline & $\mathrm{T} 3$ & $11.12 \mathrm{e}$ & $19.16^{c}$ & $0.88^{d}$ & $7.58 \mathrm{a}$ \\
\hline \multirow[t]{3}{*}{ M1H } & T1 & $12.00 \mathrm{~g}$ & $20.67 \mathrm{e}$ & 0.63 a & 8.33 a \\
\hline & $\mathrm{T} 2$ & $9.51^{c}$ & $16.39 \mathrm{~b}$ & $0.73^{b}$ & $8.20^{\mathrm{a}}$ \\
\hline & T3 & $7.90^{a}$ & $13.61^{\mathrm{a}}$ & $0.80^{b}$ & 8.09 a \\
\hline \multirow[t]{3}{*}{$\mathrm{M} 2 \mathrm{H}$} & $\mathrm{T} 1$ & $9.59 \mathrm{~d}$ & $16.52^{b}$ & $0.66^{b}$ & 8.62 a \\
\hline & $\mathrm{T} 2$ & $8.31^{b}$ & $14.33^{\mathrm{a}}$ & $0.68 \mathrm{~b}$ & 8.23 a \\
\hline & T3 & $8.25^{b}$ & $14.21^{\mathrm{a}}$ & $0.83^{c}$ & $8.15^{\mathrm{a}}$ \\
\hline \multicolumn{6}{|c|}{ Probability } \\
\hline \multicolumn{2}{|c|}{ Compost } & $<.001$ & $<.001$ & $<.001$ & NS \\
\hline \multicolumn{2}{|c|}{ Time } & $<.001$ & $<.001$ & $<.001$ & NS \\
\hline \multicolumn{2}{|c|}{ Compost*time } & $<.001$ & $<.001$ & NS & NS \\
\hline \multicolumn{2}{|c|}{ CV (\%) } & 3.9 & 3.1 & 8.0 & 5.1 \\
\hline
\end{tabular}

M1 P = Compost in pit with 75\% SCB +20\% OM+5\% Ash, $\mathbf{M 2 P}=$ Compost in pit with $95 \%$ SCB $+5 \%$ OM.

M1 $\boldsymbol{H}=$ Compost in heap with 75\% SCB +20\% OM+5\% Ash, $\mathbf{M 2} \boldsymbol{H}=$ Compost in heap with 95\% SCB+5\% OM. Same letters within columns indicate no significant differences.

\subsection{TEMPERATURE OF COMPOSTS}

Temperature (Figure 2 and 3) evolved similarly in the two mixtures and the maximum temperature in both composts was reached in the first week. From the 13rd to 34th day of composting, the temperature dropped in all pits and the maximum temperatures were $55.25^{\circ} \mathrm{C}$ and $52.3^{\circ} \mathrm{C}$ for $\mathrm{M} 1$ and $\mathrm{M} 2$ respectively (Figure 2). 


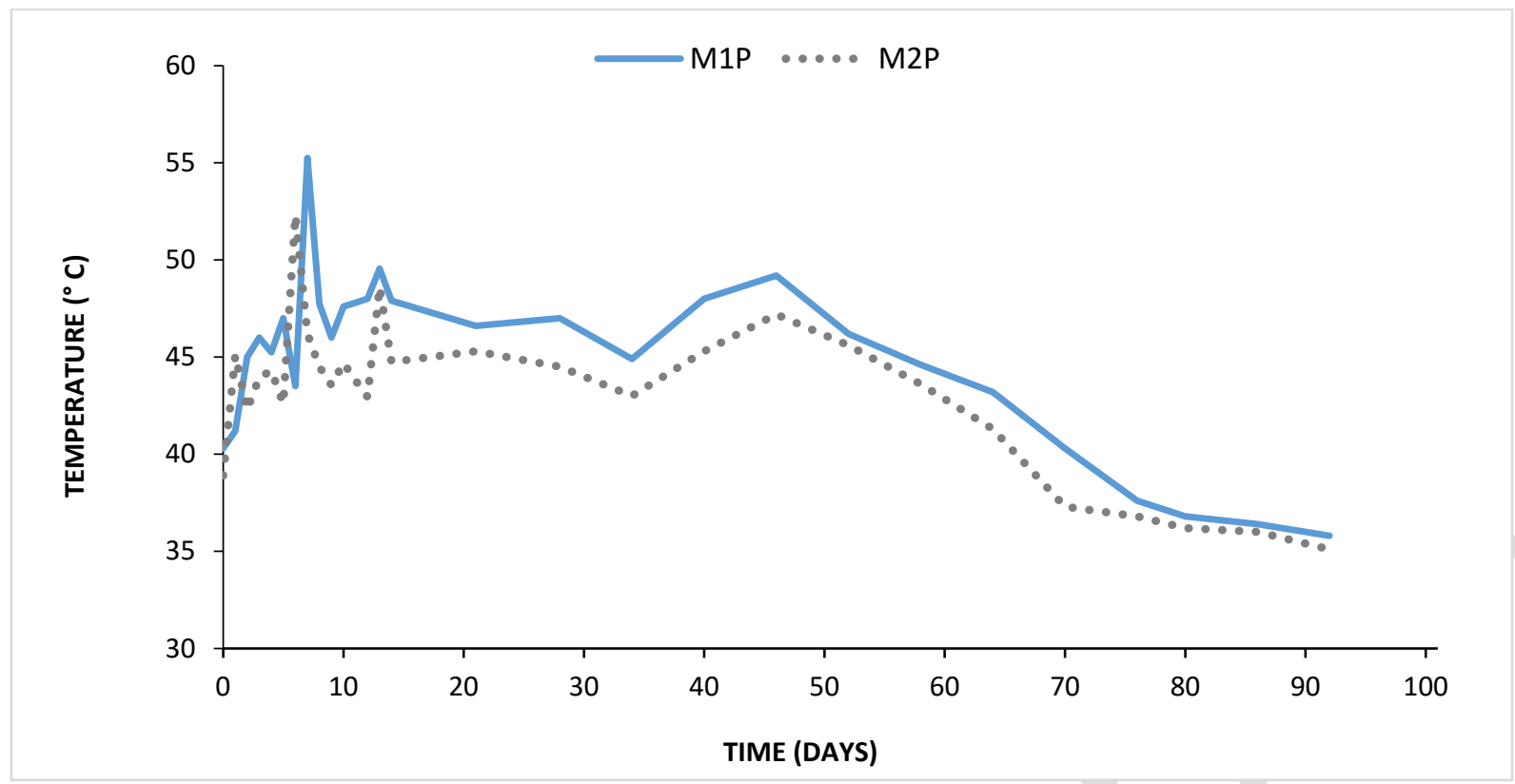

Figure 2: Variation of temperatures during the composting to the level of pits

M1P = Compost in pit with $75 \%$ SCB $+20 \%$ OM+5\% Ash, $\mathbf{M 2 P}=$ Compost in pit with $95 \%$ SCB+5\% OM.

In heap composting, the temperatures rose more slowly than in the pit compost and here the highest temperatures were reached in the second week. For heap composting, the highest temperatures reached were $48.3^{\circ} \mathrm{C}$ for $\mathrm{M} 1 \mathrm{H}$ compost and $56^{\circ} \mathrm{C}$ for $\mathrm{M} 2 \mathrm{H}$.

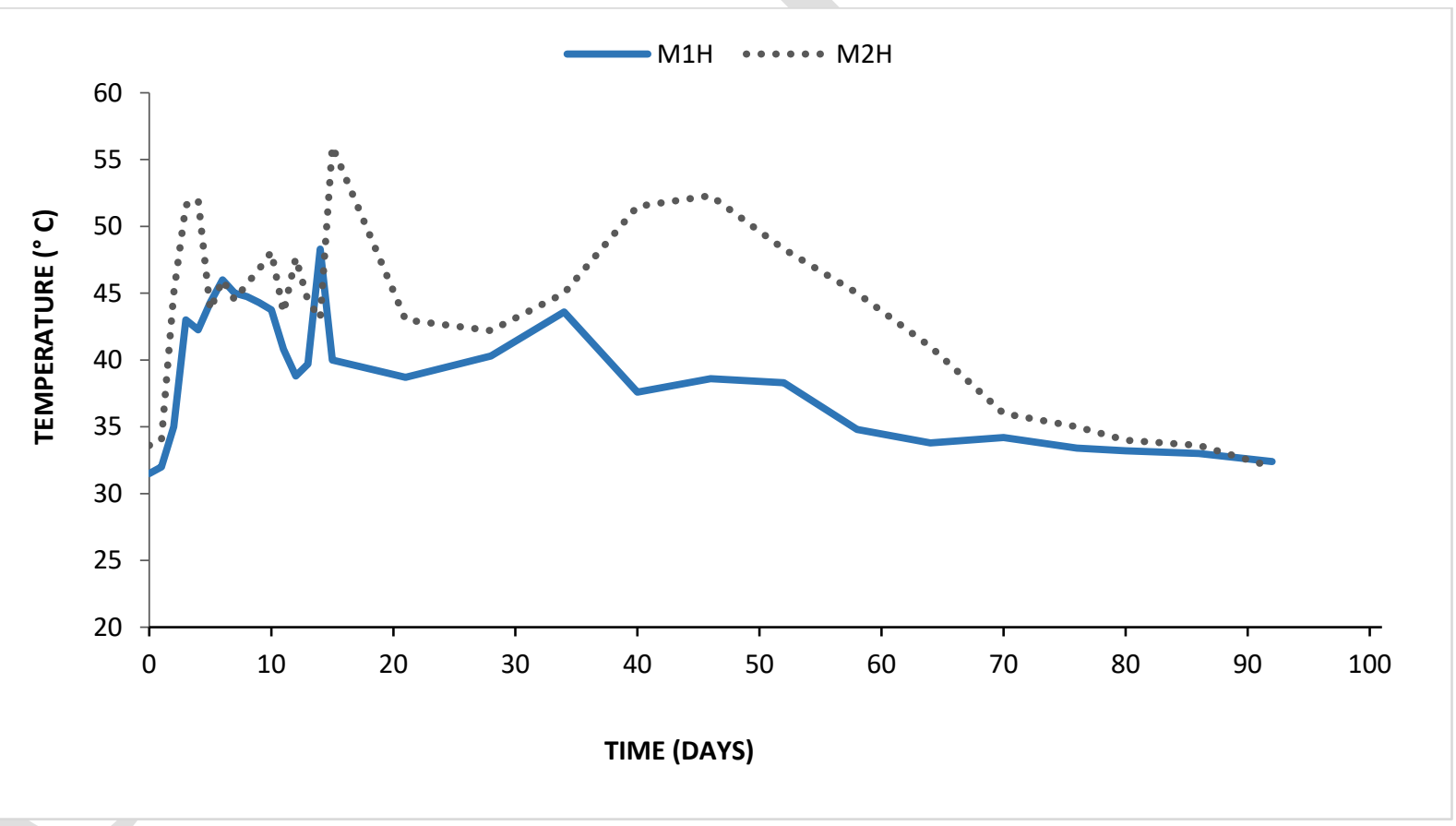

Figure 3: Variation of temperatures during composting to the level of heaps

$\mathbf{M 1 H}=$ Compost in heap with 75\% SCB +20\% OM+5\% Ash, $\mathbf{M 2 H}=$ Compost in heap with 95\% SCB +5\% OM.

\subsection{VARIATION OF THE PH}

One month after the start of composting, the different mixtures were alkali $(\mathrm{pH}>8)$ (Figure 4). A progressive reduction of $\mathrm{pH}$ during the process was observed in all composts, but this reduction is not statistically significant. 
During the 90-day period of composting, the $\mathrm{pH}$ values of composts in pit reduced from 8.3 to 7.9 for the M1P compost and from 8.17 to 7.58 for the M2P compost. For heap composting, the pH changed from 8.33 to 8.09 for the $\mathrm{M} 1 \mathrm{H}$ compost and from 8.61 to 8.14 for the M2H compost.

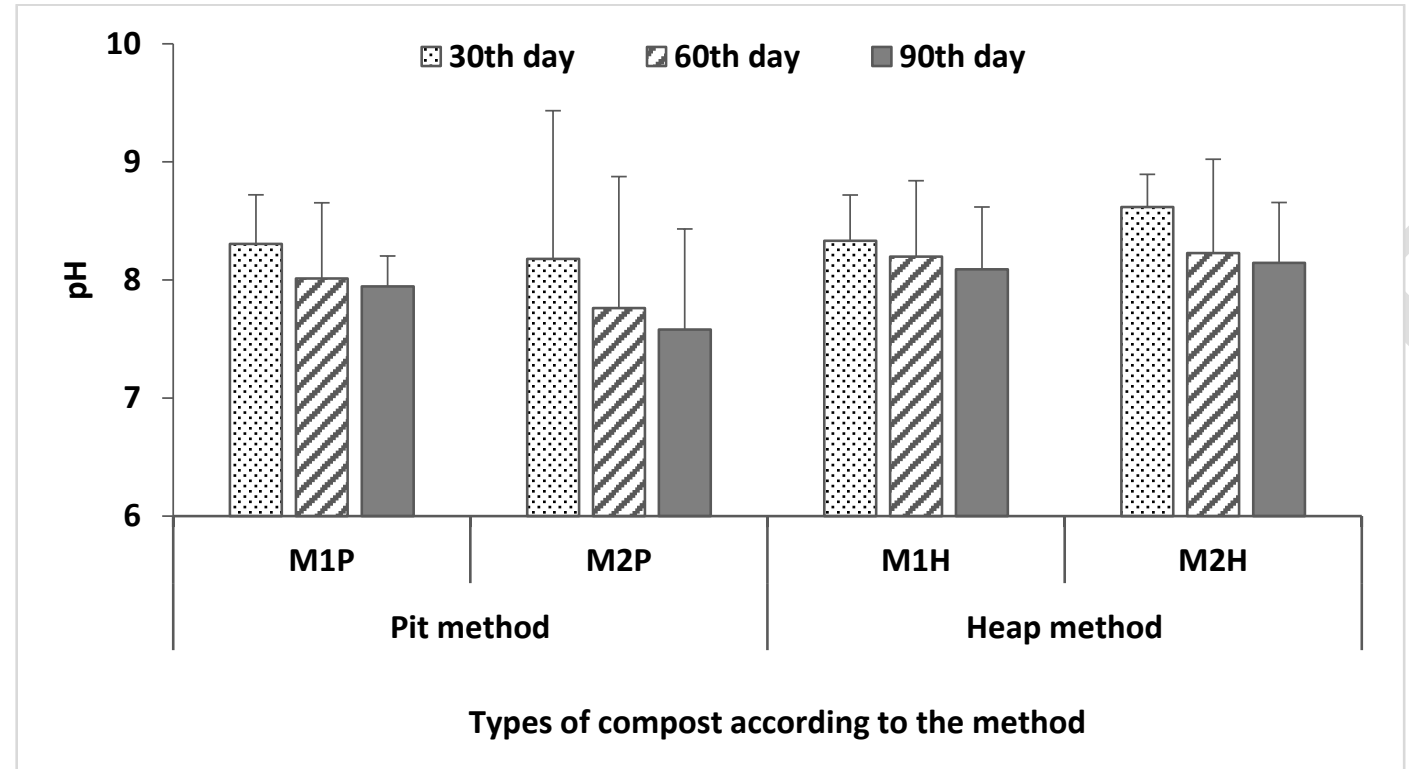

Figure 4: Variation in $\mathrm{pH}$ of the composts during the decompositions period

M1 $\boldsymbol{P}=$ Compost in pit with $75 \%$ SCB $+20 \%$ OM+5\% Ash, $\boldsymbol{M 2 P}=$ Compost in pit with $95 \%$ SCB $+5 \%$ OM. M1 $\boldsymbol{H}=$ Compost in heap with 75\% SCB +20\% OM+5\% Ash, $\boldsymbol{M} 2 \mathbf{H}=$ Compost in heap with 95\% SCB+5\% OM.

\subsection{ORGANIC CARBON}

The carbon content of the composts was reduced during the 90 days composting period (Figure 4). Statistically, this reduction was significant $(\mathrm{p}=<.001)$ at $5 \%$ threshold (Figure 5). The carbon content of the M1P compost fell from $13.0 \%$ to $12.3 \%$ and the M2P compost from $12.97 \%$ to $11.12 \%$. The carbon content of the M1H composts and M2H dropped from $12.0 \%$ to $7.9 \%$ and from $9.59 \%$ to $8.25 \%$ respectively.

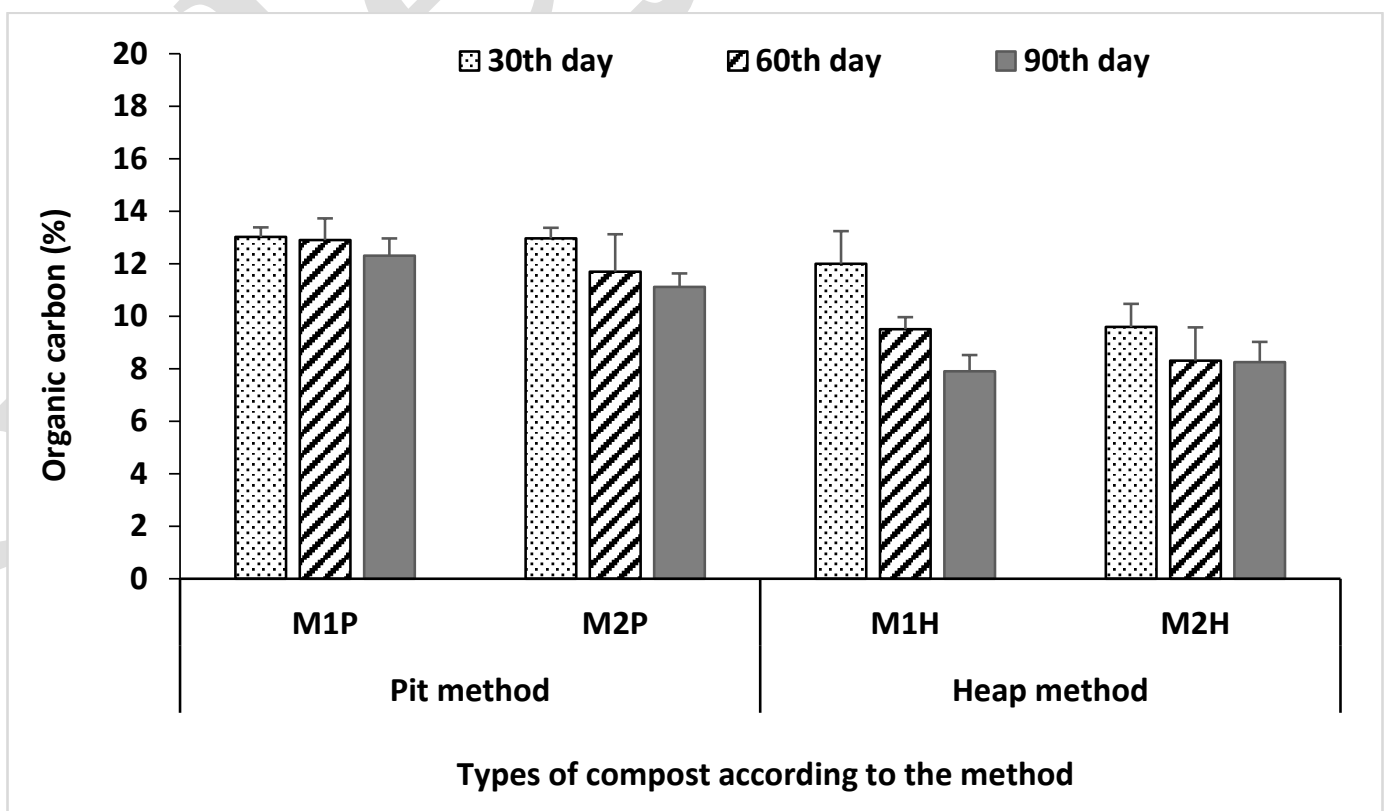

Figure 5: Variations in organic carbon during composting according to the methods and types of mixtures 
M1 P = Compost in pit with $75 \%$ SCB $+20 \%$ OM+5\% Ash, $\boldsymbol{M 2 P}=$ Compost in pit with $95 \%$ SCB $+5 \%$ OM. M1 $\boldsymbol{H}=$ Compost in heap with 75\% SCB +20\% OM+5\% Ash, $\boldsymbol{M} 2 \mathbf{H}=$ Compost in heap with 95\% SCB+5\% OM.

\subsection{TOTAL NITROGEN (N)}

The nitrogen content differed between the two composts, but also according to the periods of sampling (Figure 6). For the pit method, the nitrogen content increased significantly from the start of composting ( $\mathrm{p}<.001)$. The nitrogen content was highest for the M1P compost. On the $30^{\text {th }}$ day, this compost reached nitrogen content of $0.83 \%$ and at the end of the process (90th day), this compost had $1.11 \%$ nitrogen. With regard to the M2P compost, its nitrogen content increased between the $30^{\text {th }}$ and $90^{\text {th }}$ day from $0.77 \%$ to $0.88 \%$.

The same tendency was observed for heap composting (M1H and $\mathrm{M} 2 \mathrm{H}$ ). For the $\mathrm{M} 1 \mathrm{H}$ compost, the nitrogen content was $0.63 \%, 0.73 \%$ and $0.8 \%$ at the $30^{\text {th }}, 60^{\text {th }}$ and $90^{\text {th }}$ day respectively. For the $\mathrm{M} 2 \mathrm{H}$ compost, this content evolved from $0.66 \%$ on the $30^{\text {th }}$ day to $0.83 \%$ on the $90^{\text {th }}$ day.

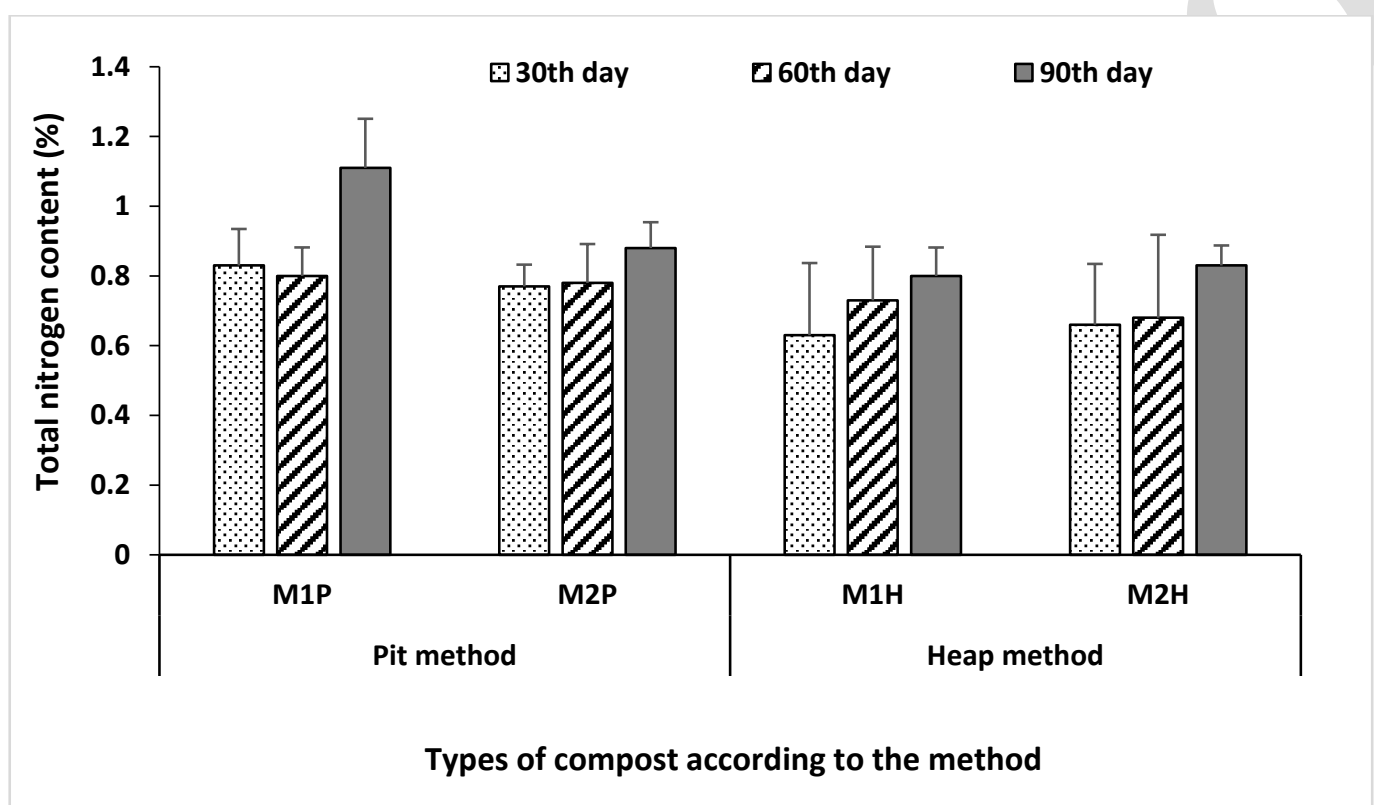

Figure 6: Variation of the total nitrogen during composting according to the methods and the types of mixtures

M1 $\boldsymbol{P}=$ Compost in pit with $75 \%$ SCB $+20 \%$ OM+5\% Ash, $\mathbf{M 2 P}=$ Compost in pit with $95 \%$ SCB $+5 \%$ OM. M1 H = Compost in heap with 75\% SCB +20\% OM+5\% Ash, M2 $\mathbf{H}=$ Compost in heap with 95\% SCB+5\% OM.

\subsection{THE C/N RATIO}

The $\mathrm{C} / \mathrm{N}$ ratio passed from 15.85 at 30 days after composting to 11.24 at 90 days after start of composting for the M1P compost and from 17.06 at 30 days to 12.75 at 90 days for the M2P compost (Figure 7).

For M1H composts and M2H, these ratios passed from 20.8 to 9.99 and from 15.41 to 10.07 respectively. 


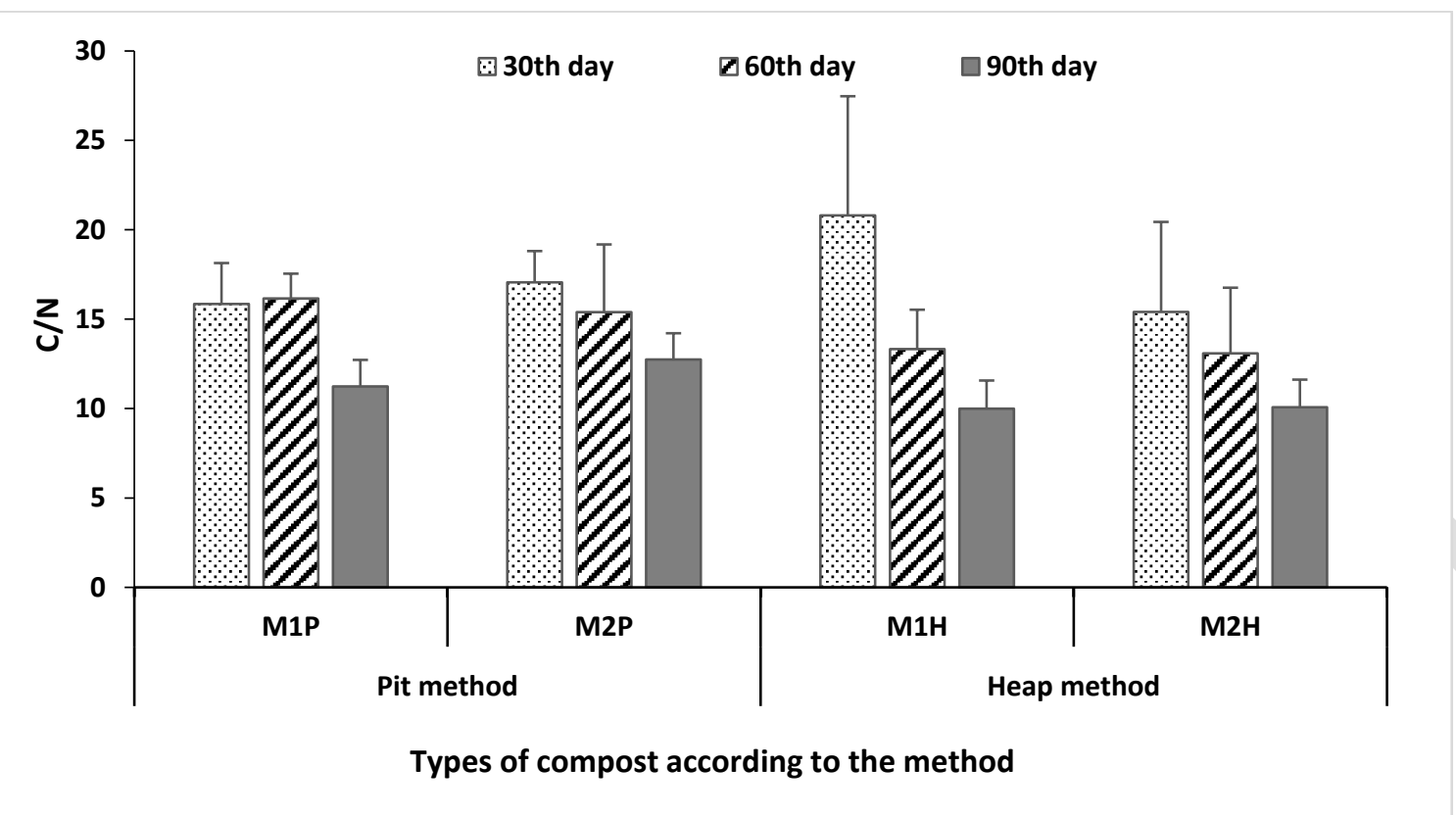

Figure 7: Variation of the $\mathrm{C} / \mathrm{N}$ ratio during composting according to the methods and the types of mixtures

M1 $\boldsymbol{P}=$ Compost in pit with $75 \%$ SCB $+20 \%$ OM+5\% Ash, $\mathbf{M 2 P}=$ Compost in pit with $95 \%$ SCB $+5 \%$ OM.

M1 $\boldsymbol{H}=$ Compost in heap with 75\% SCB $+20 \%$ OM+5\% Ash, $\mathbf{M} 2 \mathbf{H}=$ Compost in heap with 95\% SCB+5\% OM.

\subsection{PHYSICO-CHEMICAL CHARACTERISTICS OF COMPOSTS}

The analysis showed highly significant differences with regard to organic matter $(p<.001)$, nitrogen $(p=0.008)$, and potassium ( $\mathrm{p}<.001)$ (Table 3) (Sadi et al. 2019). No significant difference was observed for total and assimilated phosphorus and $\mathrm{pH}-\mathrm{H}_{2} \mathrm{O}$. The richest compost was the $\mathrm{M} 1 \mathrm{P}$ compost and this contained $12.31 \% \mathrm{C}, 1.11 \% \mathrm{~N}$ and 1026 mg K kg-1. The pit method gave a better quality than heap composting as this compost was richer in carbon, nitrogen and available phosphorus than the heap compost.

Table 3: Mean composition in physico-chemical elements of composts ( \pm SE)

\begin{tabular}{|c|c|c|c|c|c|c|c|c|}
\hline \multirow[t]{2}{*}{ Physico-chemical element } & \multicolumn{4}{|c|}{ Types of composts } & \multirow[t]{2}{*}{ F.pr (0.05) } & \multirow[t]{2}{*}{ CV (\%) } & \multicolumn{2}{|c|}{ Norme } \\
\hline & M1P & M2P & $\mathrm{M} 1 \mathrm{H}$ & $\mathrm{M} 2 \mathrm{H}$ & & & FAO & AFNOR \\
\hline $\mathrm{pH}-\mathrm{H}_{2} \mathrm{O}(1: 2.5)$ & $\begin{array}{c}7.95 \text { a } \\
( \pm 0.26) \\
\end{array}$ & $\begin{array}{c}7.58 \mathrm{a} \\
( \pm 0.85) \\
\end{array}$ & $\begin{array}{c}8.09 \mathrm{a} \\
( \pm 0.53)\end{array}$ & $\begin{array}{c}8.15 \text { a } \\
( \pm 0.51)\end{array}$ & 0.467 & 6.7 & & \\
\hline Organic matter (\%) & $\begin{array}{l}21.21 \mathrm{~b} \\
( \pm 1.13)\end{array}$ & $\begin{array}{l}19.16 \mathrm{~b} \\
( \pm 0.88)\end{array}$ & $\begin{array}{l}13.61^{a} \\
( \pm 1.07)\end{array}$ & $\begin{array}{l}14.21^{\mathrm{a}} \\
( \pm 1.33)\end{array}$ & $<.0071$ & 6.9 & $10-30$ & $>5$ \\
\hline $\mathrm{C}(\%)$ & $\begin{array}{r}12.31 \mathrm{~b} \\
( \pm 0.65)\end{array}$ & $\begin{array}{c}11.12^{\mathrm{b}} \\
( \pm 0.51)\end{array}$ & $\begin{array}{c}7.90^{a} \\
( \pm 0.62)\end{array}$ & $\begin{array}{c}8.25 \text { a } \\
( \pm 0.77)\end{array}$ & $<.001$ & 6.9 & & \\
\hline $\mathrm{N}(\%)$ & $\begin{array}{c}1.11^{b} \\
( \pm 0.14)\end{array}$ & $\begin{array}{c}0.88^{a} \\
( \pm 0.07)\end{array}$ & $\begin{array}{c}0.80^{a} \\
( \pm 0.08)\end{array}$ & $\begin{array}{c}0.83 \text { a } \\
( \pm 0.06)\end{array}$ & 0.008 & 11.3 & $0.4-0.5$ & $>0.25$ \\
\hline Available P (mg kg-1) & $\begin{array}{r}11.25^{a} \\
( \pm 1.48)\end{array}$ & $\begin{array}{c}12.76 \mathrm{a} \\
( \pm 1.46)\end{array}$ & $\begin{array}{c}9.99 \text { a } \\
( \pm 1.58)\end{array}$ & $\begin{array}{l}10.07 \mathrm{a} \\
( \pm 1.55)\end{array}$ & 0.112 & 29.8 & & \\
\hline $\mathrm{K}^{+}\left(\mathrm{mg} \mathrm{kg}^{-1}\right)$ & $\begin{array}{l}1026^{b} \\
( \pm 12.5) \\
\end{array}$ & $\begin{array}{c}975^{b} \\
( \pm 42.6)\end{array}$ & $\begin{array}{c}779 a \\
( \pm 51.2)\end{array}$ & $\begin{array}{c}814^{a} \\
( \pm 14.9)\end{array}$ & $<.001$ & 4.2 & & \\
\hline
\end{tabular}


Valorization of Sida Cordifolia L. Biomass in Compost for Pearl Millet (Pennisetum Glaucum) Production in Niger

\begin{tabular}{|c|c|c|c|c|c|c|c|c|}
\hline & & & & & & & & \\
\hline $\mathrm{C} / \mathrm{N}$ & $\begin{array}{c}11.24 \mathrm{a} \\
( \pm 1.48)\end{array}$ & $\begin{array}{c}12.75 \mathrm{a} \\
( \pm 1.46)\end{array}$ & $\begin{array}{c}9.99 \mathrm{a} \\
( \pm 1.58)\end{array}$ & $\begin{array}{c}10.07 \mathrm{a} \\
( \pm 1.55)\end{array}$ & 0.112 & 14.4 & $10-15$ & $<20$ \\
\hline
\end{tabular}

$\mathbf{M 1 P}=$ Compost in pit with $75 \%$ SCB $+20 \%$ OM+5\% Ash, $\mathbf{M 2 P}=$ Compost in pit with $95 \%$ SCB $+5 \%$ OM.

M1H $=$ Compost in heap with 75\% SCB $+20 \%$ OM+5\% Ash, $\boldsymbol{M 2} \boldsymbol{H}=$ Compost in heap with 95\% SCB+5\% OM.

FAO: Food and Agriculture Organization, AFNOR: Association French of Normalization.

tot $\boldsymbol{P}=$ total $P$ and available $\boldsymbol{P}=$ Available phosphorus.

\subsection{SAME LETTERS WITHIN LINE INDICATE NO SIGNIFICANT DIFFERENCES}

\subsubsection{TEST OF PHYTOTOXICITY}

The statistical analysis revealed a highly significant difference between the composting methods and the two mixtures on germination (Table 4). The average germination percentages obtained for M1P compost for the S1 substrates, S2 and S3 were $60.3 \%, 75.0 \%$ and $87.5 \%$ respectively. Germination decreased with increased amounts of compost in the substrate for all the compost types, but the germination was above $50 \%$, even for the pure compost types.

Table 4: Average of germination rate according to the substrates (compost rate) and the types of compost

\begin{tabular}{|c|c|c|c|c|}
\hline \multirow[t]{3}{*}{ Type of compost } & \multicolumn{3}{|c|}{ Substrates } & \multirow{3}{*}{$\begin{array}{c}\text { Control } \\
\text { (100\% sand) }\end{array}$} \\
\hline & S1 & $\mathrm{S} 2$ & 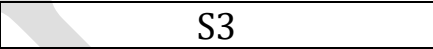 & \\
\hline & (100\% of compost) & (sand $+75 \%$ of compost) & (sand $+25 \%$ of compost) & \\
\hline M1P & $60.25^{a}$ & $75.00^{b}$ & $87.50^{c}$ & \multirow[t]{4}{*}{97.6} \\
\hline M2 P & $58.25^{a}$ & $74.50^{b}$ & $90.25^{c}$ & \\
\hline M1H & $50.75^{a}$ & $75.25 \mathrm{~b}$ & $86.75^{c}$ & \\
\hline $\mathrm{M} 2 \mathrm{H}$ & $53.00^{\mathrm{a}}$ & $68.00^{b}$ & $80.50^{c}$ & \\
\hline \multicolumn{5}{|c|}{ F pr. } \\
\hline Substrates & \multicolumn{4}{|c|}{$<.001$} \\
\hline Composts & \multicolumn{4}{|c|}{ NS } \\
\hline Substrates*Composts & \multicolumn{4}{|c|}{ NS } \\
\hline \multicolumn{5}{|c|}{ LSD } \\
\hline Substrates & \multicolumn{3}{|c|}{7.98} & \\
\hline Composts & + & 9.22 & & \\
\hline Substrates*Composts & \multicolumn{3}{|c|}{$\frac{9.22}{15.97}$} & \\
\hline
\end{tabular}

M1 P = Compost in pit with 75\% SCB +20\% OM+5\% Ash, $\boldsymbol{M 2 P}=$ Compost in pit with $95 \%$ SCB $+5 \%$ OM.

M1 H = Compost in heap with 75\% SCB +20\% OM+5\% Ash, $\mathbf{M 2} \boldsymbol{H}=$ Compost in heap with 95\% SCB+5\% OM.

Same letters within line indicate no significant differences

\subsection{EFFECTS OF PREPARED COMPOSTS BASED ON BIOMASS OF THE SC ON PEARL MILLET}

\subsubsection{DISTRIBUTION OF RAINFALL}

The distribution of rainfall the cropping season 2018 and 2019 from sowing to the harvesting is illustrated in Figure 8.

In 2018 (figure 8A), a total of $517 \mathrm{~mm}$ rainfall was obtained during the 92-day period. The most important rainfall $(73 \mathrm{~mm})$ was recorded on the $50^{\text {th }}$ day after sowing (DAS). Between the $7^{\text {th }}$ and $17^{\text {th }}$ DAS, a small dry spell was observed.

The total rainfall from sowing to harvest was $408.2 \mathrm{~mm}$ in 2019 at N'Dounga station (figure 8B). The maximal rainfall recorded was $38.8 \mathrm{~mm}$ on the $56^{\text {th }}$ DAS.

The two cropping years were characterized by a variation in rainfall distribution. In 2018, 80 days of rain were recorded while in 2019, the season lasted more than 100 days. The rain lasted between sowing and harvest. This 
variability between the two years is similar to that observed by (Issoufa et al. 2019) during a study carried out in N'Dounga station for the 2013 and 2014.

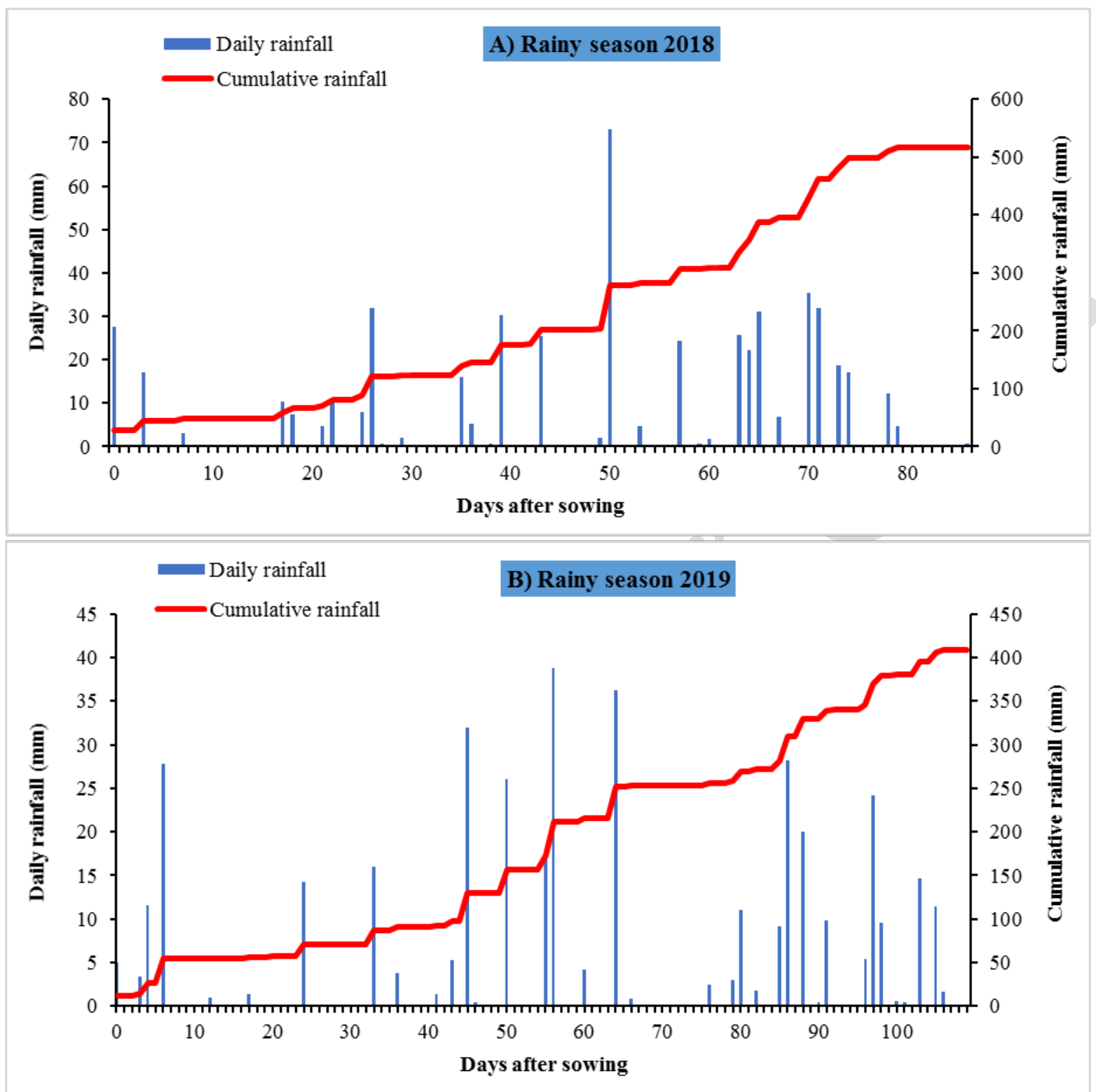

Figure 8: Rainfall distributions for N'Dounga during the cropping season 2018 and 2019

Sources: http://www.fieldclimate.com INRAN REDSAACC-3, Serial number 0020366B

\subsection{EFFECTS OF COMPOSTS ON THE MILLET GRAIN YIELD AND THE BIOMASS}

Over the two years, the treatments had a significant effect on the grain results (Table 5). The highest grain results were obtained with M1P compost applied at rates of $1000 \mathrm{~kg} \mathrm{ha}^{-1}$ and $1500 \mathrm{~kg} \mathrm{ha}^{-1}$.

In 2018 the M1P treatment increased the yield compared to the control of $652 \mathrm{~kg} \mathrm{ha}^{-1}$ (105.2\%), while in 2019 the M1P treatment increased the grain yield compared to the control of $812 \mathrm{~kg} \mathrm{ha}^{-1}$ (118.02\%). Application of 1000 $\mathrm{kg}$ of compost M1P ha-1 M1P is equivalent to $11.1 \mathrm{~kg} \mathrm{~N} \mathrm{ha}^{-1}(1000 \mathrm{~kg} * 1.11 \% \mathrm{~N})$. Treatments with pit composting gave better grain yield than heap composting. There was also a tendency for M1 compost to perform better than M2 compost. It was found that $1000 \mathrm{~kg} \mathrm{ha}^{-1}$ gave better results than $1500 \mathrm{~kg} \mathrm{ha}^{-1}$ of compost. Treatments and years had significant effects on stem yield. 
The treatment of $1000 \mathrm{~kg} \mathrm{ha}^{-1} \mathrm{M} 1 \mathrm{P}$ gave the highest yield in 2018 but also during the 2019 campaign. This treatment increased the yield of the stems compared to the control of $1377 \mathrm{~kg}$ ha- 1 in 2018 , i.e. $77.5 \%$ and $1611 \mathrm{~kg}$ ha $^{-1}$ in 2019 corresponding to $76.13 \%$.

Table 5: Mean yield in grains and in stover of HKP millet according to treatments and sites $( \pm \mathrm{SE})$

\begin{tabular}{|c|c|c|c|c|}
\hline \multirow[t]{2}{*}{ Treatments } & \multicolumn{2}{|c|}{ Grain yield (kg ha-1) } & \multicolumn{2}{|c|}{ Stover yield (kg ha-1) } \\
\hline & 2018 & 2019 & 2018 & 2019 \\
\hline Control & $620 \pm 48$ & $688 \pm 30$ & $1776 \pm 273$ & $2116 \pm 309$ \\
\hline $1000 \mathrm{~kg} \mathrm{ha}^{-1} \mathrm{M}_{1} \mathrm{P}$ & $1273 \pm 96$ & $1500 \pm 97$ & $3153 \pm 268$ & $3727 \pm 316$ \\
\hline $1500 \mathrm{~kg} \mathrm{ha}^{-1} \mathrm{M}_{1} \mathrm{P}$ & $1128 \pm 30$ & $1221 \pm 57$ & $2836 \pm 276$ & $3563 \pm 145$ \\
\hline $1000 \mathrm{~kg} \mathrm{ha}^{-1} \mathrm{M}_{2} \mathrm{P}$ & $856 \pm 70$ & $1132 \pm 81$ & $1500 \pm 193$ & $2663 \pm 419$ \\
\hline $1500 \mathrm{~kg} \mathrm{ha}^{-1} \mathrm{M}_{2} \mathrm{P}$ & $790 \pm 44$ & $952 \pm 52$ & $1565 \pm 104$ & $2502 \pm 319$ \\
\hline $1000 \mathrm{~kg} \mathrm{ha}^{-1} \mathrm{M}_{1} \mathrm{H}$ & $858 \pm 13$ & $922 \pm 30$ & $1563 \pm 182$ & $2717 \pm 419$ \\
\hline $1500 \mathrm{~kg} \mathrm{ha}^{-1} \mathrm{M}_{1} \mathrm{H}$ & $872 \pm 41$ & $1006 \pm 23$ & $1635 \pm 411$ & $2846 \pm 221$ \\
\hline $1000 \mathrm{~kg} \mathrm{ha}^{-1} \mathrm{M}_{2} \mathrm{H}$ & $692 \pm 27$ & $919 \pm 43$ & $1835 \pm 141$ & $3093 \pm 176$ \\
\hline $1500 \mathrm{~kg} \mathrm{ha}^{-1} \mathrm{M}_{2} \mathrm{H}$ & $685 \pm 26$ & $849 \pm 25$ & $1517 \pm 112$ & $2343 \pm 110$ \\
\hline \multicolumn{5}{|l|}{ Probability $(0.05)$} \\
\hline Year (Y) & \multicolumn{2}{|c|}{$<.001$} & \multicolumn{2}{|c|}{$<.001$} \\
\hline Treatments (T) & \multicolumn{2}{|c|}{$<.001$} & \multicolumn{2}{|c|}{$<.001$} \\
\hline $\mathrm{YxT}$ & \multicolumn{2}{|c|}{ NS } & \multicolumn{2}{|c|}{ NS } \\
\hline $\mathrm{CV}$ & \multicolumn{2}{|c|}{25.8} & \multicolumn{2}{|c|}{35.4} \\
\hline
\end{tabular}

M1 $\boldsymbol{P}=$ Compost in pit with $75 \%$ SCB $+20 \%$ OM+5\% Ash, $\boldsymbol{M 2 P}=$ Compost in pit with $95 \%$ SCB $+5 \%$ OM.

M1 $\boldsymbol{H}=$ Compost in heap with 75\% SCB $+20 \%$ OM+5\% Ash, $\boldsymbol{M} 2 \mathbf{H}=$ Compost in heap with 95\% SCB+5\% OM. Same letters within columns indicate no significant differences

\subsection{AGRONOMIC EFFICIENCY OF NITROGEN (AE-N) FOR THE FOUR COMPOSTS}

Highly significant differences at $5 \%$ were obtained between treatments and years $(\mathrm{p}<.001)$.

The agronomic nitrogen use efficiency varied from 10 to $59 \mathrm{~kg}_{\text {grain }} \mathrm{kg}^{-1} \mathrm{~N}$ in 2018 and from 24 to $78 \mathrm{~kg}$ grain $\mathrm{kg} \mathrm{N}^{-1}$ in 2019 (Table 6). For the two years, the treatment $1000 \mathrm{~kg} \mathrm{ha}^{-1} \mathrm{M} 1 \mathrm{P}$ gave the highest nitrogen use efficiency. In terms of the grain yield, the nitrogen use efficiency was higher in the compost produced in pit as compared to the compost produced in heap.

Table 6: Analysis of the grain yield and the agronomic efficiency of the treatments $( \pm \mathrm{SE})$

\begin{tabular}{|c|c|c|}
\hline \multirow[t]{2}{*}{ Treatments } & \multicolumn{2}{|c|}{ N Agronomic Efficiency (N -AE-) kg grain $\mathrm{kg}^{-1} \mathrm{~N}$ (dry weight) } \\
\hline & 2018 & 2019 \\
\hline Control & $P$ & - \\
\hline $1000 \mathrm{~kg} \mathrm{ha}^{-1} \mathrm{M}_{1} \mathrm{P}$ & $59 \pm 8$ & $78 \pm 8$ \\
\hline $1500 \mathrm{~kg} \mathrm{ha}^{-1} \mathrm{M}_{1} \mathrm{P}$ & $47 \pm 3$ & $55 \pm 5$ \\
\hline $1000 \mathrm{~kg} \mathrm{ha}^{-1} \mathrm{M}_{2} \mathrm{P}$ & $24 \pm 6$ & $47 \pm 7$ \\
\hline $1500 \mathrm{~kg} \mathrm{ha}^{-1} \mathrm{M}_{2} \mathrm{P}$ & $19 \pm 4$ & $32 \pm 4$ \\
\hline $1000 \mathrm{~kg} \mathrm{ha}^{-1} \mathrm{M}_{1} \mathrm{H}$ & $24 \pm 1$ & $30 \pm 2$ \\
\hline $1500 \mathrm{~kg} \mathrm{ha}^{-1} \mathrm{M}_{1} \mathrm{H}$ & $26 \pm 3$ & $37 \pm 2$ \\
\hline $1000 \mathrm{~kg} \mathrm{ha}^{-1} \mathrm{M}_{2} \mathrm{H}$ & $11 \pm 2$ & $30 \pm 4$ \\
\hline $1500 \mathrm{~kg} \mathrm{ha}^{-1} \mathrm{M}_{2} \mathrm{H}$ & $10 \pm 2$ & $24 \pm 2$ \\
\hline \multicolumn{3}{|l|}{ Probability } \\
\hline Year $(\mathrm{Y})$ & \multicolumn{2}{|c|}{$<.001$} \\
\hline Treatments (T) & \multicolumn{2}{|c|}{$<.001$} \\
\hline $\mathrm{YxT}$ & \multicolumn{2}{|c|}{ NS } \\
\hline $\mathrm{CV}$ & \multicolumn{2}{|c|}{38.1} \\
\hline
\end{tabular}




\begin{abstract}
M1 P = Compost in pit with 75\% SCB +20\% OM+5\% Ash, $\boldsymbol{M 2 P}=$ Compost in pit with $95 \%$ SCB $+5 \%$ OM. M1 $\boldsymbol{H}=$ Compost in heap with 75\% SCB $+20 \%$ OM+5\% Ash, $\mathbf{M} 2 \mathbf{H}=$ Compost in heap with 95\% SCB+5\% OM. Same letters within columns indicate no significant differences
\end{abstract}

\title{
4. DISCUSSION
}

\subsection{EVOLUTION OF THE PHYSICO-CHEMICAL CHARACTERISTICS DURING COMPOSTING}

There was no clear difference in maximum temperatures developed in pit composting as compared to heap composing. In pit composing there is probably a cooling effect because the compost is placed below ground, but at the same time the heat loss is lower because the compost is less exposed to air. In heap composting there is probably a greater heat loss because the compost is more exposed to the air. These effects operate in different directions and explain why there is no major difference in maximum temperature between pit and heap composting. However, it was observed that maximum temperature was reached two weeks later when heap composting was used, compared to pit composting.

The maximum temperatures obtained in this study varied from 48.3 for the $\mathrm{M} 1 \mathrm{H}$ compost to $56^{\circ} \mathrm{C}$ for the $\mathrm{M} 2 \mathrm{H}$ compost. The maximum temperatures are similar to those obtained by (Tchegueni and Kili 2011). However, typical maximum temperatures in composting is between $60^{\circ} \mathrm{C}$ and $70^{\circ} \mathrm{C}$ (Mustin 1987). The low quantity of compost production could be the cause for the low maximum temperatures. Quantities should be greater than $500 \mathrm{~kg}$ in order to achieve maximum temperatures higher than $60^{\circ} \mathrm{C}$. Such temperatures destroy all the pathogenic organisms (Tchegueni and Kili 2011).

The end temperature in the different composts was close to ambient temperature $\left(44.9^{\circ} \mathrm{C}\right)$ which indicates that the decomposition was almost complete (Mustin 1987).

The $\mathrm{pH}$ was significantly reduced during the composting period. Soil organic carbon was also reduced during the decomposition process. The microorganisms use the organic matter as a substance for their metabolism, thereby reducing the carbon content of the compost through the release of $\mathrm{CO}_{2}$ (Francou 2003, Adamou et al. 2018).

During the process of composting, the nitrogen percentage increased in all composts. This could in part be related to the residues of microbes and bacteria that have multiplied especially during the first phase composting (Mustin 1987). It can also be assumed that part of the increase in nitrogen is due to the effect of the release of carbon during the decomposition period which increased the relative content of nitrogen compared to carbon in the compost, thereby lowering the $\mathrm{C} / \mathrm{N}$ ratio (Tchegueni and Kili 2011, Adamou et al. 2018). Compost to be used as a fertilizer should have a C/N ratio below 15-20 according to the FAO norm, and all the composts produced in this study fulfilled this criterion.

\subsection{TEST OF PHYTOTOXICITY ON MILLET}

A mature compost will have a non-toxic effect on germinating plants (Tiquia et al. 1997). In this study, different concentrations of the composts were used to test the phytotoxicity on germination of pearl millet. The phytotoxicity test of the composts showed that the incorporation of a dose of $25 \%$ of the M1P, M2P, M1H and M2H compost gave a germination rate of $87.5 \%, 90.3 \%, 86.8 \%$ and $80.5 \%$ respectively. The pure composts gave a germination rate of between 50 and $60 \%$. Compost is considered non-toxic when germination is beyond $50 \%$ (Luo et al. 2018).

All four types of composts in this study gave germination rates beyond $50 \%$. Therefore, these composts can be applied to millet without causing germination inhibition as the concentration of compost will be low after mixing with the soil, as under field conditions.

The germination and the good quality of sowings indicate that the composts are deprived of substances phenolic which can block germination and growth of the seedlings (Sullivan and Miller 2001).

\subsection{PHYSICO-CHEMICAL FEATURES OF PREPARED COMPOSTS}

The $\mathrm{C} / \mathrm{N}$ ratio of composts was relatively low. Composts produced from the mixture of $75 \%$ of the SC, $20 \%$ of the $\mathrm{OM}$ and $5 \%$ of the ash have a lower $\mathrm{C} / \mathrm{N}$ ratio than the compost produced from $95 \% \mathrm{SC}$ and $5 \% \mathrm{OM}$. This result was the same for both pit and heap composting. 
Valorization of Sida Cordifolia L. Biomass in Compost for Pearl Millet (Pennisetum Glaucum) Production in Niger

Compared to the norms of the FAO, the contents in organic matter and in nitrogen are acceptable. The $\mathrm{C} / \mathrm{N}$ ratio obtained in this study is close to optimum (Nanéma 2007). This ratio will give a rapid release of nitrogen as this ratio is close to the $\mathrm{C} / \mathrm{N}$ ratio of soil.

\subsection{EFFECTS OF COMPOSTS ON GRAIN YIELD AND BIOMASS OF MILLET HKP}

Application of composts improved millet yield compared to the control during both cropping seasons (2018 and 2019). Improved crop yields through composting may be linked to better crop development due to the increased availability of compost nutrients (Badar et al. 2015). Studies by (Fatondji et al. 2009) have also shown an increase in grain and biomass yields from millet resulting from a gradual release of nutrients from composts. M1P compost gave the highest grain yield, possibly because this compost contains more nitrogen and potassium than other composts. This compost is also richer in organic matter, which can over time improve the physical properties of the soil.

Application of compost at a rate of $1000 \mathrm{~kg} \mathrm{ha}^{-1}$ gave a higher yield than application of $1500 \mathrm{~kg}$ ha- 1 of compost in both seasons. The rate of $1000 \mathrm{~kg} \mathrm{ha}^{-1}$ of M1P compost corresponds to $11.1 \mathrm{~kg} \mathrm{~N} \mathrm{ha}^{-1}$. If $20 \mathrm{~kg} \mathrm{ha}^{-1} \mathrm{NPK} \mathrm{15-15-15}$ is applied as a microdose, the nitrogen application rate is $3 \mathrm{~kg} \mathrm{~N}^{-1}$. The M1P compost will also add approximately $0.0113 \mathrm{~kg}$ P ha- 1 over the $3 \mathrm{~kg} \mathrm{P}^{-1}$ applied when $20 \mathrm{~kg}$ of NPK 15-15-15 ha-1 is applied as previously recommended. The nitrogen content is therefore more than three times higher in the treatment of $1000 \mathrm{~kg} \mathrm{M}^{\mathrm{P}} \mathrm{Pa}^{-1}$ than when 20 $\mathrm{kg}$ of NPK ha-1 are applied. In Sudan and Mali, it has been reported that it is possible to use rates as low as $3 \mathrm{~kg}$ NPK (15-15-15) ha-1 (Aune et al. 2007, Aune and Ousman 2011). This result may also indicate that it is possible to allocate $500 \mathrm{~kg}$ of compost ha-1 instead of $1000 \mathrm{~kg} \mathrm{ha}^{-1}$. It has already been shown that micro-dosing of mineral fertilizers gives good results in the Sahel, but our results also come that it is also possible to practice micro-dosing of organic fertilizer using available local resources. In addition, the results of this study illustrate the principle in precision agriculture that when a resource is in scarcity, as organic matter in this case, it should not be applied by diffusion in the field, but rather applied to the plantation hill (Aune et al. 2017). It is also a less labor intensive and more efficient way.

\subsection{AGRONOMIC EFFICIENCY OF NITROGEN (AE-N)}

During the two years (2018 and 2019), application of $1000 \mathrm{~kg}$. ha-1 of M1P compost gave the highest N-AE with respectively $59 \mathrm{~kg}$ of grain $\mathrm{kg}^{-1} \mathrm{~N}$ and $78 \mathrm{~kg}$ of grain $\mathrm{kg}^{-1} \mathrm{~N}$. This can be attributed mainly to the amount of nitrogen contained in this compost (11.1g.kg-1) which is higher than that of other composts. Also, this compost gave the highest results in 2018 (1273 $\pm 96 \mathrm{~kg}$. ha-1) and in 2019 (1500 $\pm 97 \mathrm{~kg}$. ha-1). In general, a tangency of the increase in E-N with the decrease in the dose of the compost except at the level of the M1H compost. This could be due to the low proportion of nitrogen contained in this compost which is $0.8 \%$ or $8 \mathrm{~g}$. ha-1. Our results are in contrast with those of with those of (Cassman et al. 2002) who report that the reduction of nitrogen fertilizers greatly improves the EAN.

\section{CONCLUSION}

The results from this study show that it is possible to produce a high-quality compost based on Sida cordifolia (SC) within 90 days. The compost that gave the best yield results consisted of $75 \%$ SC, $20 \%$ OM and 5\% ash (M1P). The compost will not be toxic on germination when applied to the soil. In 2018, the $1000 \mathrm{~kg} \mathrm{ha}^{-1} \mathrm{M} 1 \mathrm{P}$ treatment increased the yield compared to the control by $652 \mathrm{~kg} \mathrm{ha}^{-1}(105.2 \%)$, while in 2019 this M1P treatment increased the grain yield compared to the control of $812 \mathrm{~kg} \mathrm{ha}^{-1}(118.02 \%)$.

The amount of nitrogen applied in $1000 \mathrm{~kg}$ compost ha-1 (100 g compost hill-1) was more than three times the amount applied compared to $20 \mathrm{~kg} \mathrm{NPK} \mathrm{ha}^{-1}\left(2 \mathrm{~g} \mathrm{NPK} \mathrm{hill}^{-1}\right)$. However, the composts are low in phosphorus making it necessary to supplement with phosphorus from mineral fertilizer or rock phosphates. The results from this study

suggest that it should be interesting for the farmers to harvest Sida cordifolia L. for compost production, thereby reducing infestation of this invasive weed species. This compost can be used as a supplement to mineral fertilizer. 


\section{SOURCES OF FUNDING}

The research was funded by the Norwegian Ministry of Foreign Affairs through Norwegian embassy in Bamako, Mali.

\section{CONFLICT OF INTEREST}

The author have declared that no competing interests exist.

\section{ACKNOWLEDGMENT}

The authors would like to thank the Department of International Environment and Development Studies, Norwegian University of Life Sciences, Ås, Norway.we also thank CARE and INRAN in Niger.

\section{REFERENCES}

[1] Adamou, Z., M. M. Tchicama, A. Kiari Saidou, and O. Garba. 2018. Development of Compost from Agro-food Residues: Analysis of the Crop Nutrients and Trace Elements. American Scientific Research Journal for Engineering, Technology, and Sciences (ASRJETS) 43:1-12.

[2] Aune, J. B., A. Coulibaly, and K. E. Giller. 2017. Precision farming for increased land and labour productivity in semi-arid West Africa. A review. Agronomy for sustainable development 37:16.

[3] Aune, J. B., M. Doumbia, and A. Berthe. 2007. Microfertilizing sorghum and pearl millet in Mali: Agronomic, economic and social feasibility. Outlook on agriculture 36:199-203.

[4] Aune, J. B., and A. Ousman. 2011. Effect of seed priming and micro-dosing of fertilizer on sorghum and pearl millet in Western Sudan. Experimental Agriculture 47:419-430.

[5] Badar, R., M. Khan, B. Batool, and S. Shabbir. 2015. Effects of organic amendments in comparison with chemical fertilizer on cowpea growth. International Journal of Applied Research 1:66-71.

[6] Baidu-Forson, J. 1995. Determinants of the availability of adequate millet stover for mulching in the Sahel. Journal of Sustainable Agriculture 5:101-116.

[7] Bationo, A., and A. Buerkert. 2001. Soil organic carbon management for sustainable land use in SudanoSahelian West Africa. Pages 131-142 Managing Organic Matter in Tropical Soils: Scope and Limitations. Springer.

[8] Cassman, K. G., A. Dobermann, and D. T. Walters. 2002. Agroecosystems, nitrogen-use efficiency, and nitrogen management. AMBIO: A Journal of the Human Environment 31:132-140.

[9] Chaibou. 2000. Sida cordifolia L dans l'espace agraire de quelques terroirs villageois du Sud-ouest nigérien, Mémoire CRESA Université Abdou Moumouni de Niamey, Niger. p51.

[10] Fatondji, D., C. Martius, R. Zougmore, P. L. Vlek, C. L. Bielders, and S. Koala. 2009. Decomposition of organic amendment and nutrient release under the zai technique in the Sahel. Nutrient cycling in agroecosystems 85:225.

[11] Francou, C. 2003. Stabilisation de la matière organique au cours du compostage: influence de la nature du déchet et du procédé de compostage, recherche d'indicateurs pertinents. Thèse de l'Institut national Agronomique de Paris-Grignon, 288p.

[12] Issoufa, B. B., A. Ibrahim, R. C. Abaidoo, and N. Ewusi-Mensah. 2019. Combined use of millet glume-derived compost and mineral fertilizer enhances soil microbial biomass and pearl millet yields in a low-input millet cropping system in Niger. Archives of Agronomy and Soil Science 65:1107-1119.

[13] Luo, Y., J. Liang, G. Zeng, M. Chen, D. Mo, G. Li, and D. Zhang. 2018. Seed germination test for toxicity evaluation of compost: Its roles, problems and prospects. Waste management 71:109-114.

[14] Misra, R., R. Roy, and H. Hiraoka. 2005. Méthodes de compostage au niveau de l'exploitation agricole. FAO. ed. Rome.

[15] Mustin, M. 1987. Le compost: gestion de la matière organique F. Dubusc eds, pp. 957, Paris.

[16] Nanéma, S. 2007. Compostage et évaluation de l'efficacité agronomique du compost de déchets urbains solides de la ville de Bobo-Dioulasso. Mémoire d'ingénieur, IPR/IFRA, Katiébougou (Mali), 67p. 
[17] Ouédraogo, E., A. Mando, and N. Zombré. 2001. Use of compost to improve soil properties and crop productivity under low input agricultural system in West Africa. Agriculture, Ecosystems \& Environment 84:259-266.

[18] Richard, T. L., H. Hamelers, A. Veeken, and T. Silva. 2002. Moisture relationships in composting processes. Compost Science \& Utilization 10:286-302.

[19] Saadou, M. 1990. La végétation des milieux drainés à l'est du fleuve Niger. Thèse d'Etat présentée à la faculté des sciences de l'Université de Niamey, p 395.

[20] Sadi, S. M., A. K. Saidou, M. Boubé, and J. B. Aune. 2019. Mineralization and Decomposition of Four Types of Compost Based on Biomass of Sida cordifolia L. in a Sandy Soil in the Semi-arid Zone of Niger. International Journal of Plant \& Soil Science 31(3):1-13.

[21] Sullivan, D. M., and R. O. Miller. 2001. Compost quality attributes, measurements, and variability. In Stofella, P.J. et B.A. Kahn (Eds.). Compost utilization in horticultural cropping systems. Lewis Publishers, New York, USA.:95-120.

[22] Tchegueni, S., and K. Kili. 2011. Contribution à la valorisation des déchets agro-alimentaires en compost: Caractérisation physico-chimique des composts et étude de leur minéralisation dans deux sols agricoles du Togo. Thèse de Doctorat, Université de Lomé TOG0, pp1-13.

[23] Tiquia, S., N. Tam, and I. Hodgkiss. 1997. Effects of turning frequency on composting of spent pig-manure sawdust litter. Bioresource Technology 62:37-42.

[24] Van Reeuwijk, L. 1993. Procedures for Soil Analysis. International Soil Reference and Information Centre (ISRIC). Wageningen. Netherlands.

[25] Vanlauwe, B., J. Kihara, P. Chivenge, P. Pypers, R. Coe, and J. Six. 2011. Agronomic use efficiency of N fertilizer in maize-based systems in sub-Saharan Africa within the context of integrated soil fertility management. Plant and soil 339:35-50.

[26] Walkley, A., and I. A. Black. 1934. An examination of the Degtjareff method for determining soil organic matter, and a proposed modification of the chromic acid titration method. Soil science 37:29-38. 